\title{
FORUM
}

\section{"BEER WITH CHINESE CHARACTERISTICS": MARKETING BEER UNDER MAO}

\author{
"Cerveja com características chinesas": Marketing de cerveja sob o regime maoista \\ "Cerveza con características chinas": Comercialización de cerveza bajo Mao
}

\section{JEFFREY PILCHER}

jeffrey.pilcher@utoronto.ca

ORCID: 0000-0002-3540-5310

\section{YU WANG}

gengshi.wang@mail.utoronto.ca ORCID: 0000-0001-9109-9015

\section{YUEBIN JACKSON GUO'}

jacksonyuebin.guo@mail.utoronto.ca ORCID:0000-0002-5931-6689

${ }^{1}$ University of Toronto, Department of History, Toronto, ON, Canada

\begin{abstract}
This essay explores the nationalization of beer in twentieth-century China. Using the theoretical framework of "culinary infrastructure," it shows how the physical facilities and technologies of brewing and marketing interacted with local drinking cultures to shape the understandings of beer in China. It begins by describing how a western consumer good originally marketed to colonial representatives was gradually adopted by the urban Chinese as a symbol of modernity in the first half of the twentieth century. It then reviews the nationalization of foreign-owned breweries and the growth of domestic production in the first decades of Communist rule. The essay concludes that the Chinese acquired a taste for beer as an everyday marker of urban privilege that survived Maoist radicalism and remains to this day a defining feature of Communist China.
\end{abstract}

KEYWORDS | Beer, China, Great Leap Forward, socialist marketing, nationalism.

\section{RESUMO}

Este estudo explora a nacionalização da cerveja na China no século XX. Usando o quadro teórico da "infraestrutura culinária", mostra como as instalações físicas e tecnologias de fabricação e comercialização interagiram com culturas locais de bebida para moldar os entendimentos de cerveja na China. Começa por descrever como um bem de consumo ocidental originalmente comercializado por representantes coloniais foi gradualmente adotado pelo chinês urbano como símbolo da modernidade na primeira metade do século XX. Em seguida, analisa a nacionalização das cervejarias de propriedade estrangeira e o crescimento da produção doméstica nas primeiras décadas do regime comunista. $O$ estudo conclui que os chineses adquiriram o gosto pela cerveja como marca diária de privilégios urbanos que sobreviveu ao radicalismo maoísta e permanece até hoje uma característica definidora da China comunista.

PALAVRAS-CHAVE / Cerveja, China, Grande Salto Adiante, marketing socialista, nacionalismo.

\section{RESUMEN}

Este ensayo explora la nacionalización de la cerveza en la China del siglo XX. Usando el marco teórico de "infraestructura culinaria", muestra cómo las instalaciones físicas y tecnologías de producción de cerveza y comercialización interactuaron con las culturas de beber locales para formar los entendimientos de la cerveza en China. Comienza describiendo cómo un bien de consumo occidental originalmente comercializado a representantes coloniales fue adoptado gradualmente por los chinos urbanos como símbolo de modernidad en la primera mitad del siglo XX. Entonces, reseña la nacionalización de cerveceras de propiedad de extranjeros y el crecimiento de la producción local en las primeras décadas del gobierno comunista. El ensayo concluye que los chinos adquirieron el gusto por la cerveza como un marcador cotidiano de privilegio urbano que sobrevivió al radicalismo maoísta y permanece hasta hoy como una característica definitoria de la China comunista.

PALABRAS CLAVE / Cerveza, China, Gran Salto Adelante, comercialización socialista, nacionalismo. 


\section{INTRODUCTION}

China's recent global economic ascendancy has prompted widespread attention to the country's particular version of state capitalism, which the architect of economic reform, Deng Xiaoping, labeled "socialism with Chinese characteristics." As is the case in countless other industries, China is also the world's largest producer of beer, and attempts by international firms to enter the Chinese market since the 1990 s have met with limited success. To explain the ability of Chinese brewers to compete with more technically advanced foreign rivals, the economist Junfei Bai and his coauthors emphasized the distinctive nature of the local market, paraphrasing Deng's slogan with "beer" in place of "socialism." They cited Chinese preferences for undifferentiated quality, low price, and unique tastes, such as that for clam-juice beer, as evidence that foreign firms selling premium brands “just do not 'get' the China beer market" (Bai, Huang, Rozelle, \& Boswell, 2011, p. 184).

Although local knowledge is unquestionably vital for successful marketing, evaluating the development of the Chinese beer industry from a historical perspective also requires careful attention to chronology. Noting that beer remained a luxury until economic reform began in 1978, Bai and his colleagues pointed to the 1990 s as the turning point in Chinese brewing. This interpretation fits within a broader social science literature emphasizing the transformative nature of consumerism following the privations of the Great Leap Famine (1959-1961) and the Cultural Revolution (1966-1976) (Jun, 2000; Davis, 2000; Latham, Thompson, \& Klein, 2006; Gerth, 2010; Li, 2010). But historians have noted important antecedents to contemporary industrial modernity and consumer culture in early-twentiethcentury China (Cochran, 1999; Lu, 1999; Gerth, 2003; Dikötter, 2006). Both social scientists and historians have largely shared the assumption that the growth of Chinese consumerism was temporarily suppressed under the rule of Mao Zedong, who insisted that people be provided with the "necessary" but not the "superfluous" (Hoffmann, 1971). Nevertheless, beer had become enough of a necessity in China that the number of breweries increased more than tenfold between 1949 and 1976. Whereas only about seven firms served a largely foreign clientele on the eve of the Communist revolution, the hundred or more breweries operating at the time of Mao's death set the stage for reform-era growth (Zhu, Qi, \& Wu, 1980).

One historical study that spans the twentieth century-Zhiguo Yang's exemplary account of the brewery in Qingdao-emphasizes the progressive nationalization of beer in China. Founded in 1903 by German colonists, the brewery adopted the colonial spelling Tsingtau, later Tsingtao, and served a predominantly European clientele. When Japanese forces seized the German concession in Shandong Province during World War I, the new owners sought to market the beer to local consumers; however, sales remained low because the Chinese had not yet acquired much of a taste for beer. After World War II, the Nationalist managers hoped to expand Tsingtao's sales in major cities, such as Shanghai and Nanjing, but made little progress due to the instability caused by the civil war. When the Communists took over, they saw the brewery as a valuable source of foreign revenue, and the beer was not marketed nationally until the $1990 \mathrm{~s}$ (Yang, 2007). Because of its distinctive origins and export markets, the brewery at Qingdao can offer only limited insights on the wider Chinese beer industry.

Building on Yang's work, this essay explores the nationalization of beer throughout twentieth-century China with a special focus on the Maoist period. It adopts the theoretical framework of "culinary infrastructure" to show how the physical facilities and technologies of brewing and marketing interacted with local drinking cultures to shape the understandings of beer in China (Pilcher, 2016; Wilson, 2005). The narrative begins by examining how a western consumer good originally marketed to colonial representatives was gradually adopted by urban Chinese as a symbol of modernity in the first half of the twentieth century. It then outlines the nationalization of foreign-owned breweries and the growth of domestic production in the first decades of Communist rule. The essay concludes that the Chinese acquired a taste for beer as an everyday marker of urban privilege that survived Maoist radicalism and remains to this day a defining feature of Communist China (Eyferth, 2009; Brown, 2012).

\section{MAKING BEER CHINESE}

Upon first tasting beer in 1905, a Chinese consumer spat out: "Ugh, what kind of black brew is this? It looks like medicine! And that foam on top! You can't drink it-not on your life!" (Höllmann, 2014, p. 149). Although this particular encounter with dark Russian ale may have been more extreme than the usual reaction to light German lagers, western beer did not gain immediate acceptance among Chinese drinking cultures. The problem was not with alcohol per se, because the Chinese have been making and drinking intoxicating beverages for thousands of years. Nor was it necessarily the bitter taste of beer; few would consider the shots of baijiu (distilled spirits) traditionally consumed during banquets as mild (Smart, 2005; Shen \& Wang, 1998). Instead, the association of beer with imperialist powers meant that the appeal 
of the beverage, which might otherwise have been appreciated by many, was originally limited to progressive, urban Chinese. These modernists, often writers for western-style newspapers that proliferated around the turn of the century, played a crucial role in the domestication of beer. Together with the brewers themselves, they tried to strike a fine balance between the foreign and the national, emphasizing the allure of modernity while preserving connections with Chinese antiquity (Gerth, 2003).

Westerners introduced beer to China in the nineteenth century, and it remained for some time a source of imperial distinction. Merchants imported beer to the colony of Hong Kong, the "treaty ports" of Shanghai and Tianjin, and even interior provinces, such as Hunan (Parsons, 1900). Russians established the first breweries in China around 1900 in the Northeastern cities of Harbin and Mukden to supply beer to workers on the Trans-Manchurian Railway. A few years later, Germans founded two breweries in their Shandong concessionthe Brauerei Germania with its Tsingtao brand and Brauerei Gomoll, which specialized in Berlin-style Weissbier ("Bierausfuhr aus Japan," 1908; Ohlmer, 1914; United States. Dept. of State, \& United States. Bureau of Foreign Commerce, 1908). Investors from the United States financed the Oriental Brewery in Hong Kong in 1909, but the firm failed after just a few years and the machinery was shipped to Manila, where it supplied American colonial troops engaged in suppressing a Philippine insurgency ("Beer Making in China," 1910; "Fred Hauswirth, Brewmaster", 1918). Shanghai, with the largest concentration of foreigners, supported two breweries at various times. The Union Brewery was founded in 1911 by German or French interests, sold to Norwegian businessmen in 1919, and held briefly by the flamboyant real estate mogul Victor Sassoon around 1935. At about that time, the British trading company Jardine Matheson built a new brewery in a striking modernist building located on the waterfront (Zhu \& Qi, 1981).

Despite these various western enterprises, Japan was the imperial power most dedicated to building local markets for beer. Beginning with the Meiji era (1868-1912), Japanese officials were determined to modernize the country and adopt European technology and culture, including beer. Two firms, Dai Nippon (Great Japanese) and Kirin (a mythological beast), had consolidated the domestic beer market by 1906 and looked abroad for growth in places such has Manchuria, where the Japanese had recently defeated the Russian army (Alexander, 2013). A German journalist optimistically declared: “In China, as in Korea, the local population is turning ever more toward a taste for beer" (Globus, 1906, p. 339). Nevertheless, Japanese imports had undercut German brands among Chinese consumers as well as Japanese merchants (Berichte Consularämter, 1908, p. 37). Dai Nippon's construction of a factory in Shenyang around 1910 and its acquisition of the Tsingtao Brewery in 1916 extended its control over the nascent Chinese market (Smith, 2012).

The first Chinese-owned brewery, Shuanghesheng (Double Prosperity), was founded in Beijing in 1914 by Zhang Tingge, or perhaps purchased from the previous Swiss owners. Zhang was born in a peasant family in 1875 and moved to Vladivostok at the age of twenty-one. He learned to speak Russian and partnered with a friend in 1898 to open a grocery store, the original Shuanghesheng. With the outbreak of war in 1904, the cooperative prospered by supplying the Russian Army, and perhaps impressed by the soldiers' thirst for beer, Zhang moved to Beijing in 1914 and began brewing Five Star beer (Zhang, 2008; Zhang, 2014). Newspaper accounts described the sensory experience of the factory, including the unusual fragrance of beer and the overwhelming noise of the machinery. Unaware that hops were native to China, reporters explained that the flavoring of kuhua (bitter flowers) had formerly been imported from Russia but were now purchased in the United States. The company developed local sources for malt using barley grown in nearby Heibei province. Fermentation was carried out in underground chambers using pure yeast imported from Copenhagen and natural ice. Austrian and Czech technicians oversaw a workforce of 200 Chinese laborers. Cases were shipped from the nearby Guanganmen train Station to markets in Hangzhou, Shanghai, and as far away as Southeast Asia ("Sanyue shisan," 1920; “Beiping Shuanghesheng," 1932).

This success inspired Chinese entrepreneurs to open breweries at Yantai, Tianjin, and Hangzhou in the 1920 s (Woodhead, 1926, pp.170-171), but it was another decade before China had its first native brewmaster, Zhu Mei (see Figure 1). Although little is known of his background, he studied at the Pasteur Institute in Paris in 1931 and graduate from the Belgian National Brewing Institute in 1935. After a year of practical training at the Brasserie Chasse Royale in Brussels, he returned to China and began work at the Yantai Brewery (Yang, 2007; Xu, 1939a). Founded in 1921 near Qingdao, the company had originally employed an Austrian brewer, and built strong markets in Shanghai, although financial problems caused it to be taken over by the Bank of China in 1934 (Godley 1986). The Chinese expert saved the company money on spurious foreign expenses charged by the previous brewer, who had pocketed $\$ 5,000$ annually for chemicals to produce carbonated gas that was actually a natural product of fermentation. Zhu also solved the problem of coldweather turbidity, eliminating winter-time returns from retailers (Zhu, 1991; Zhu, 1939a). 
Figure 1. Zhu Mei, China's First Brewmaster

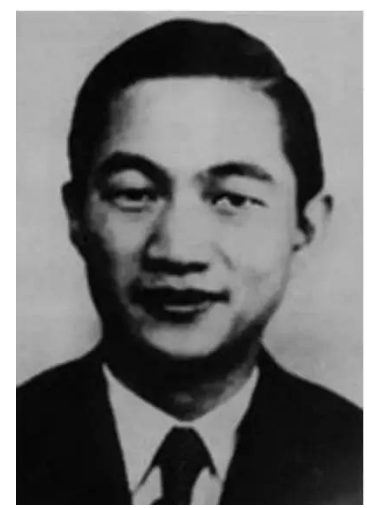

Note: Courtesy of Qingdao Beer Museum.

The infrastructure for marketing consumer goods had already become well established in Chinese port cities by the early twentieth century, as can be seen in a 1917 report by the United States consul in Shanghai, Thomas Sammons. He advised potential exporters to ship only light colored beers, noting that "there seems to be little or no demand for dark beers upon this market." Notwithstanding the lack of a dedicated American liquor merchant in Shanghai, he recommended working through American merchants, for although a specialized alcohol broker might have a better distribution network, he warned about the tendency of "these dealers to push the goods of their respective countries." His advice for publicizing new beer brands differed little from that of any modern city at the time. "Newspaper advertising, first in Shanghai, to be followed later by insertions in leading Tientsin and Hankow papers, is a minimum requirement." These could be followed up by inexpensive "novelties, handbills and calendars, and also by the display of posters on walls and signboards, in street cars, and on slides in motion-picture houses" (“Foreign Trade Opportunities," 1917, pp. 136-137).

So who were the first Chinese beer drinkers? We know a few exceptional figures, and their examples point to broader social histories and drinking cultures, especially among modernist intellectuals with foreign connections. Jiang Zhiyou (1866-1929), a venerable magistrate and supporter of the radical journalist Liang Qichao, reputedly loved drinking beer and would order it whenever he went to a restaurant in Shanghai $(\mathrm{Xu}, 1917)$. As the historian Mark Swislocki (2009) has observed, such restaurants were an important site for cross-cultural exchange, not only between Chinese and westerners, but also among migrants from different regions of China. By the 1930s, beer had reportedly spread from western restaurants in Shanghai to traditional Chinese dining places in Beijing as well (Xiao, 1937). The Shanghai writer Zheng Yimei (1928) pointed to another common site for drinking when he recalled having tasted beer for the first time in a Russian brothel. The historian Catherine Yeh (2006) has explained how courtesans in Shanghai's Foreign Settlements served as important cultural brokers, creating status for themselves through their mastery of both Western and Chinese culture. Just as intellectuals and courtesans moved across ethnic and class lines, beer reached into working-class Chinese neighborhoods. The historian Hanchao Lu (1999) has described how manual laborers, students, and clerks gathered at pulou guan (proletarian restaurants) to eat porridge and noodles and to drink beer and Chinese alcohol purchased from nearby wine shops.

When advertisers promoted beer, they emphasized a modern lifestyle and European quality, even while drawing on Chinese cultural references. The historian Norman Smith, in his book Intoxicating Manchuria, has described the way early Japanese beer advertisements displayed their international pedigree by using text in three languages: English, Japanese, and Chinese. The images portrayed men and women in western clothing and modern situations (Smith, 2012). Later on, perhaps responding to nationalist pressure, foreign brewers made more attempts to localize their products. In the early 1940s, the Japanese management at Qingdao created an advertisement recalling the classic Romance of the Three Kingdoms, in which three ancient Chinese folk heroes took an oath of brotherhood while drinking (Yang, 2007).

Logos provided an important form of branding, particularly for marketers seeking to broaden their customer base beyond the educated elite. The original Germania Brewery in Qingdao had appealed to colonists with imagery of the imperial eagle and classical European female figures. Japanese advertisers took the trouble of translating brand names into Chinese, but remained heavily invested in their own imperial iconography of the rising sun. Dai Nippon translated its flagship brand Asahi as Taiyang (sunlight), while the breweries in Shenyang and Qingdao produced new products named Da Yang (Big Sun) and Hong Xing (Red Star) (Smith, 2012). Only in 1946, after the defeat of the Japanese, did Nationalist Chinese managers at Qingdao adopt the city's iconic harbor lighthouse as the brewery's logo, and even then, they used a simple cartoon at first (see Figure 2). A few years later an artist refined the image with the classic modernist lines that still appear on bottles of Tsingtao to this day (see Figure 3). Other logos used in the 1930 s included Yantai's "Immortal Island," "Two-Headed Birds," and "Three Glories"; Shuanghesheng's "Five Star"; and the Guangzhou Brewery's “Five Goats," a beloved local symbol (“Domestically Produced Beer," 1935; Reports of Guangdong, 1937).

Unlike advertisers, Chinese intellectuals writing about beer sought to trace a native genealogy for the beverage within the 
broad category for alcohol, jiu 酒. Beer was transliterated in the early twentieth century as pi jiu 啤酒, although at first some used an alternate character, 皮酒, meaning “skin.” Another early term, mentioned by Xu Ke in his Qing bai lei chao (Collection of Anecdotes and Romances of the Qing Period, 1917), was mai jiu 麥酒, literally a fermented alcoholic beverage made of wheat or barley. Xu noted a reference from the Han Dynasty (25-220 CE) of mai jiu being brewed by Fan Ran in honor of a friend's appointment to the bureaucracy. This genealogy continued to be elaborated by later authors. In 1982, Cao Zongye pointed to another early Chinese version of beer known as $l i$ 醴泉, a sweet, thin alcoholic beverage made from nie 雀 (malt). Cao quoted the Ming Dynasty scientist and scholar Song Yingxing (1587-1666): "Since ancient times, people have used $q u$ 秚 (wine yeast) to produce jiu and nie to produce li. Later on, people detested the thin taste of li and discarded the methods of making nie.” Thus, Cao concluded, "we can regard China as one of the oldest birthplaces of beer" (Cao, 1982, p. 133).

Images of beer in newspapers, whether intended as product placements or simply depictions of modern life, situated the western beverage within Chinese drinking rituals-both good and bad. A photo from 1948 of seven, clean-cut young men sitting around a banquet table in matching workers' coveralls was captioned "Fat chicken and beer are perfect for the Chinese Spring Festival.” This jovial Chinese New Year celebration contrasted with a menacing reference to competitive masculine drinking from 1944. A barrelchested man in a gangster-style coat and hat, framed by two open beer bottles in the foreground and a shelf full of bottles behind, held up a mug to the camera and challenged the reader: "Twenty bottles of beer, let's empty them!” (Yin, 1944). When women did appear along with beer, they were often associated with production rather than consumption, for example, in an image of female factory workers (“Pijiu gongchang,” 1941).

Figure 2. Tsingtao Beer Label, brewed for export, c. 1946

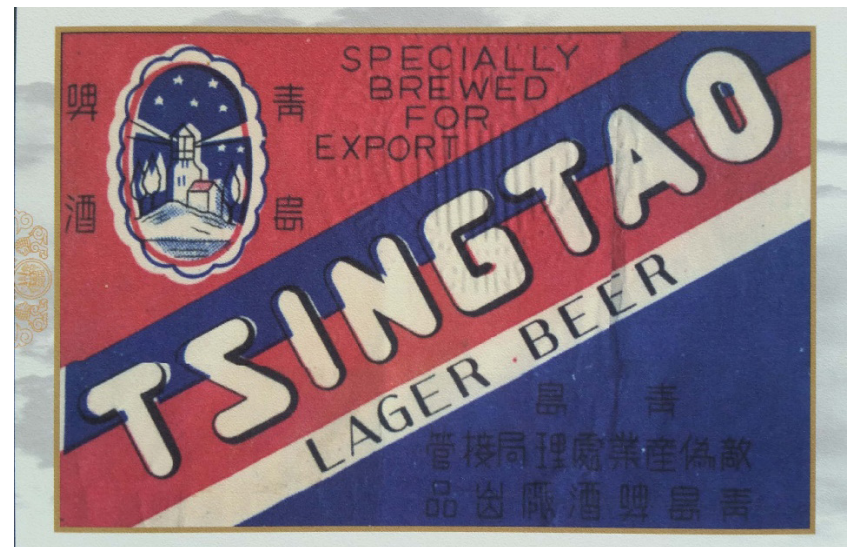

Note: Courtesy of Qingdao Beer Museum.
Figure 3. Tsingtao Beer Label, brewed for export, c. 1947

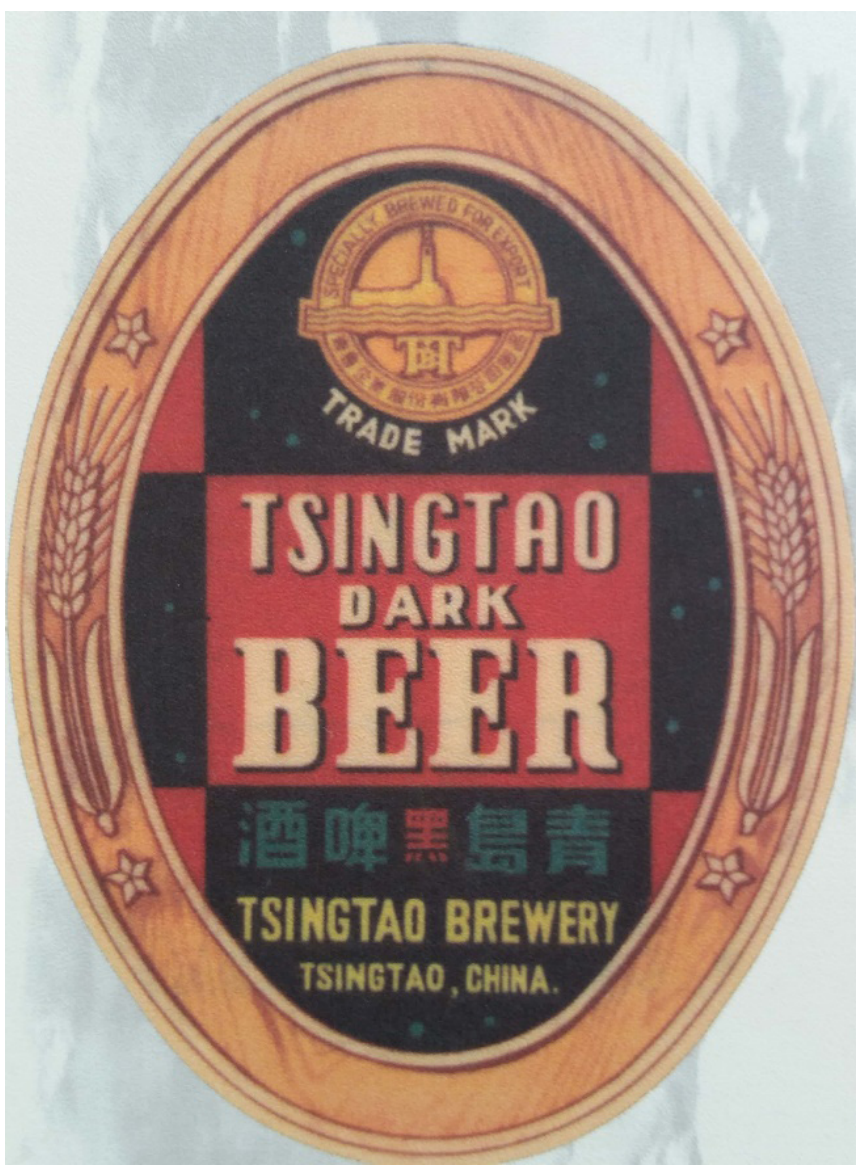

Note: Courtesy of Qingdao Beer Museum.

Chinese brewers and intellectuals at times joined together in overt nationalistic opposition to foreign brewers, particularly from Japan. Beer was included in a boycott of Japanese goods declared in 1920 in response to the continued occupation of Qingdao after the end of World War I, and protests against the 1931 invasion of Manchuria extended all the way to Chinese merchants in Burma, who refused to carry Japanese-made beers ("Beer and Boycott," 1920; "The Brewing Industry in Japan," 1932; Yang, 2007). In his book China Made, the historian Karl Gerth reproduced a 1930 image from the daily Shenbao (Shanghai News) entitled "Bashing Foreign Beer" in which "an angry cudgelwielding bottle of 'national product beer' and two drinking glasses chase after three bottles of 'foreign beer"' (Gerth, 2003, p. 320). When the Nationalists took over the Tsingtao Brewery in 1946, their advertisements emphasized the Chinese character of the beer, by highlighting, for example, the quality of Laoshan spring water (Yang, 2007).

Even while grounding beer in local traditions, Chinese authors also emphasized the health benefits and sensory 
pleasures of beer. Xu Ke (1917) differentiated the western drink from traditional Chinese liquors by emphasizing the lively bubbles within bottles of beer, which aided digestion and prevent food from decaying inside the body. Likewise, the journalist Xiao $\mathrm{Zu}$ 1937, pp. 74-75 introduced beer to Chinese consumers as a luxury beverage with beneficial effects: "In a banquet, with snow white tablecloth and colorful lights in the air, the golden fluid is served in a glass. ... In early summer, a sip of beer makes one feel buoyant, like entering into a cool world that in which all troubles are gone." The emphasis on drinking beer in the summer fit with Chinese humoral beliefs which discouraged the consumption of cold food or beverages during winter. Meanwhile, Yantai's brewmaster Zhu Mei cited western nutritional experts Wilbur Atwater and Max Rubner in newspaper articles explaining the health benefits of beer (Zhu, 1939b).

On the eve of the Communist Revolution in 1949, western beer had made only limited inroads among Chinese consumers. Of the dozen or so breweries founded in China during the first half of the twentieth century, only seven were still in operation, mostly in the northeastern part of the country, with the breweries in Shanghai and Guangzhou being exceptions. Even these factories were in poor shape after two decades of foreign invasion and civil war. Total output from the national industry amounted to a mere 7 million liters, and consumption was limited to the urban middle classes, especially intellectuals, and some well-off workers (Zhu \& Qi, 1981). Nevertheless, Chinese brewers and modernists had succeeded in localizing the product to such an extent that the Communists sought to revitalize production of beer rather than ban it as a symbol of western imperialism and bourgeois decadence.

\section{Beer and revolution in China}

In January 1958, Chairman Mao called for a Great Leap Forward, a massive program of industrial modernization and agricultural collectivization, which was intended to launch China to the top ranks of industrial nations but instead resulted in a famine that killed some 30 million people (Thaxton, 2008; Dikötter, 2010). Although generally associated with heavy industry, particularly the disastrous attempt to build backyard steel mills, the Great Leap also sought to increase production of consumer goods, including beer. Unlike steel, which could only be effectively produced in large-scale factories, beer could in fact be brewed successfully in small-scale communal factories, and output peaked at 146 million liters in 1960 - in the midst of the great famine (Zhu \& Qi, 1991). The image of party cadres and factory workers drinking beer while farmers starved in the countryside offers a telling portrait of rural-urban inequality that pervaded Maoist attempts to modernize China.

Notwithstanding dramatic policy reversals over its first quarter century, the Chinese Communist Party (CCP) remained unwavering in its pursuit of industrialization. The Party embraced foreign technical knowledge, and considered the prevalence of small-scale industry in the countryside, including countless distilleries for making baijiu, as an obstacle to industrial modernity. Agriculture remained largely in private hands through the First Five Year Plan (1953-1957), as party leaders debated whether collectivization could precede industrialization, but with the Great Leap Forward, Mao pushed ahead with plans to exploit the agricultural base to finance industry. In the disastrous aftermath of the famine, reformers sought to offer higher prices to rural producers, but grain self-sufficiency for village collectives remained a central goal until Mao's death, and agricultural production remained relatively stagnant. Meanwhile, party leaders did not consider industrialization simply as an end in itself but rather as contributing to a rise in the standard of living, particularly for urban workers, and beer became an expression of that goal.

In the first years of the revolution, beer was a low priority for the CCP, which did little more than nationalize existing factories. Government ownership of the brewery in Qingdao ensured a smooth transition to Communist management, but the case of Jardine Matheson's Ewo Brewery in Shanghai was more complicated. The Communist regime sought to assert its economic interests, without incurring the cost of outright appropriation, by revoking concessions that had been made to foreign enterprises. In 1952, Jardine Matheson declared the brewery bankrupt and sold it to the government, which renamed the firm Huaguang (Light of China) (Yang, 2007; Shai, 1989).

Nationalization also required the development of local supply chains and skilled technicians. Foreign-owned breweries had insisted on importing raw materials from Europe and North America, while keeping technical knowledge of brewing secret from Chinese workers. The economic embargo imposed on the People's Republic during the Korean War added new urgency to finding local sources of barley, hops, and yeast. Such efforts had begun decades earlier, when brewers at Shuanghesheng had recognized the nearby province of Hebei as an excellent source of European-style two-rowed barley. Likewise, in his time at the Yantai Brewery, Zhu Mei had begun breeding yeast to save the cost of importing dried yeast from the Carlsberg Laboratory in Copenhagen. Meanwhile, during the occupation of Manchuria, the Japanese had built a hop-drying facility near Yimianpo in Heilongjiang province. While 
expanding these initiatives, the government also sought to train a skilled workforce. In 1952, the Ministry of Light Industry transferred Zhu Mei from Qingdao to Shanghai to replace foreign technicians at the nationalized Huaguang Brewery. He later recalled: "I felt it was my responsibility to teach the workers how to operate the machinery and to explain the theory behind it. It was too slow to hold classes, so I ended up working together with them and taught them through actual practice" (Zhu, 1991, p. 49; see also Yang, 2007; Zhu, Qi, \& Wu, 1980).

Marketing beer posed another challenge as the new regime sought to develop socialist alternatives to capitalist commerce. The Tsingtao Brewery, which began exporting beer in 1954 to overseas Chinese customers in Hong Kong and Southeast Asia to earn much needed foreign currency, fell under the jurisdiction of the Ministry of Foreign Trade (Yang, 2007). Within the domestic market, officials recognized that few Chinese people had acquired a taste for beer and most lacked the income to purchase it on a regular basis. Factory output of beer, like other commodities, was distributed under the bureaucratic system of tonggou tongxiao (unified purchase and guaranteed sale) intended to maximize production with little regard for market demand (Solinger, 1984). In practice, beer was largely reserved for party elites, which gave it a measure of socialist distinction. The former Shuanghesheng, renamed as Capital Brewery's venerable Five Star brand, became the official beer for state banquets at the Great Hall of the People, reportedly at the behest of Premier Zhou Enlai, who drank beer in Europe in the 1920s. Marketing was also closely tied to Communist propaganda; for example, the Beijing Brewery commemorated the Revolution's tenth anniversary in 1959 by launching a premium brand called Beijing Special (Cao, 1982).

Chinese beer production more than doubled with the Great Leap Forward and then dropped by $40 \%$ as a result of the famine (see Graph 1). The Ministry of Light Industry provided the impetus for the initial growth in April 1958 by convening a conference at the Yuquan Model Brewery near Harbin with representatives from sixteen provinces and cities. The choice of Harbin rather than Tsingtao carried symbolic weight as the site of China's first brewery, established by Russians, a Cold War ally. Indeed, Russian technical writings dominated a five-volume series, Zhijiu yicong 制酒译丛 [Collection of Translated Articles on Brewing], published between 1957 and 1959. Yuquan also served as a model because of its small size and focus on domestic consumption, unlike the giant, export-oriented factory in Qingdao. Zhu Mei explained the goals of the conference in a short volume called Zenyang ban xiaoxing pijiuchang 怎样办小型啤酒厂 [How to Run a Small-Scale Brewery]. After touting the health benefits and good taste of beer, he lamented that, except for those in coastal cities of Shanghai and Guangzhou, Chinese breweries remained concentrated in the Northeast, and the costs of shipping beer to interior provinces was prohibitive. Zhu then explained the skills needed to run a small brewery, including sanitizing equipment, boiling, mashing, fermenting, and packaging in bottles or kegs. He concluded: "Most Chinese cities need beer, and they need it urgently" (Kraus, 2015).

\section{Graph 1. Chinese beer production, 1949-1967 (million liters)}

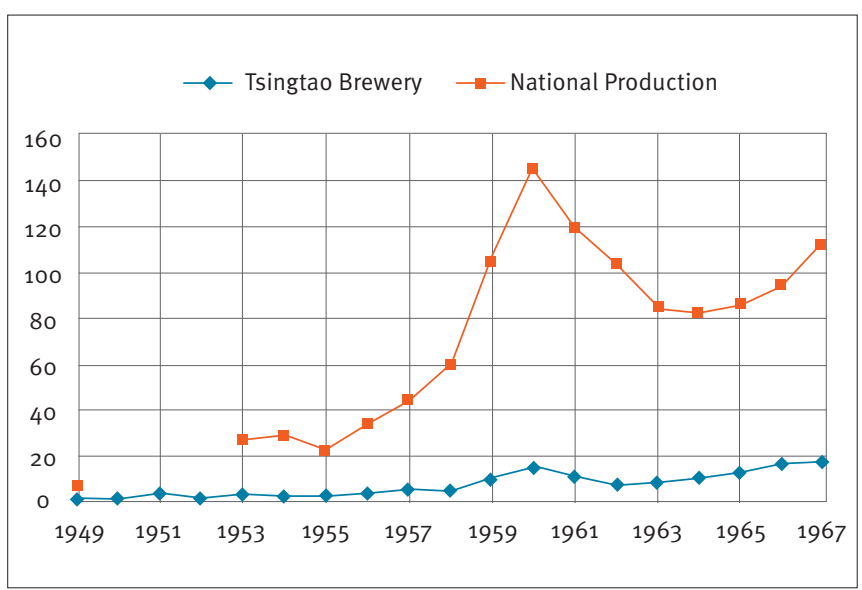

Sources: Zhu \& Qi (1981, pp. 41-54); Guo (2006, p. 188).

To facilitate this national expansion, the Chinese government made ambitious plans to increase supplies of raw materials. Brewers experimented with new sources of malt, especially maize, which was grown widely in the north as a source of animal feed and had long been used as a brewing adjunct in the United States (Tsingtao National Brewery, 1958). Meanwhile, at a National Hop Conference held in 1958, Du Zhiduan, the Minister for Light Industry, set a goal of achieving self-sufficiency in hop production within three years. Qi Zhidao, manager of the Tsingtao Brewery, encouraged local cooperatives to grow hops, supplying them with vines and growing racks. The farmers were reluctant at first to sacrifice their autonomy to a single purchaser, but they prospered from steady sales to the brewery. The Ministry of Light Industry eventually established a network of experimental hop farms throughout the country, both in coastal industrial centers such as Tianjin, Shanghai, and Zhejiang, as well as in more remote locations of Gansu, Xinjiang, and Inner Mongolia (Zhu, 1990).

Despite the surge in output, the Great Leap did not achieve the stated goal of the Yuquan Conference, and brewing remained concentrated in coastal industrial cities, particularly in the Northeast. Such a geographical distribution fit more with the unstated purpose of the Great Leap, exploiting agriculture to finance industrialization. In 1959 and 1960, China exported 
6 million tons of grain, even as national production fell by more than 50 million tons (Ash, 2006). Nevertheless, the Tsingtao Brewery remained China's only significant beer exporter at the time, and it accounted for no more than $10 \%$ of national production. Admittedly, urban workers also suffered during the Great Famine, although not on the scale of rural starvation (Brown, 2012). Even discounting exaggerated production figures, the Great Leap clearly made beer more available to privileged sectors of society-including party cadres, the military, and workers in strategic industries-at the expense of China's peasantry.

Although beer production declined for the next five years, industrial consolidation set the stage for slow but steady growth throughout the Cultural Revolution (see Graph 2). Even as the reformers Deng Xiaping and Liu Shaoqi temporarily sidelined Mao in the aftermath of the Great Leap, central planning remained fundamental to Chinese economic policy. In 1964 , the Ministry of Light Industry convened a second brewing conference at the flagship brewery, declaring: "The beer industry should learn from Qingdao" ("Qingdao pijiu”, n.d.). The move from Harbin was a part reflection of the 1960 Soviet-Chinese split, but equally important was the shift away from smallscale brewing that had been encouraged by the publication of Zhu Mei's 1958 book. Technicians assembled at Qingdao in 1964 produced a comprehensive volume entitled Tsingtao pijiu caozuofa [Operating Methods of the Tsingtao Brewery] as a handbook for the entire industry ("1964 quanguo", n.d.; Hong, 2001). Encouraged by growing demand among ethnic Chinese consumers in Hong Kong and Southeast Asia, the Ministry of Light Industry made significant investments in the 1960 s and 1970 s to increase capacity at Qingdao. Nevertheless, officials sought to balance export growth with the demands of domestic breweries in Shanghai and other major cities (Yang, 2007). Meanwhile, the government consolidated hop production in two remote western provinces of Gansu and Xinjiang, where dry climate made for irrigated and favorable growing conditions, and which freed up periurban agricultural land for more valuable truck farming, since the hops could easily be dried and shipped to breweries (Luo, n.d.).

By the 1970s, beer had become a typical consumer good in socialist China, with all the shortages, inequalities, and imperfections that this entailed. Access to consumer goods was generally determined by workplace, with staple foods distributed at the end of the week or before holidays. The Ministry of Light Industry also maintained a network of stores, where shoppers could make purchases with ration books and coupons, if they could find anything on the shelves (Davis,
2000). Under Chinese socialism, the quality of goods was ranked by “fame” (mingsheng 名声) instead of price. Tsingtao Beer was declared a "famous alcoholic beverage" at the Second National Alcohol Exhibition in 1963, and therefore, qualified for national distribution, although it was mostly reserved for export. Provincial bureaucrats distributed "locally famous alcoholic beverages," such as Shenyang Snow, Shanghai Seagull, and Beijing Special beers within the urban markets where they were produced (Cao, 1982). The Qingdao Gazetteer left a revealing record of beer's availability in the brewing capital of China: "After 1970, on the National Day and Spring Festival, every household could get five bottles of beer with their coupons. Draught beer was open for supply, though inconsistently" (Qingdao shizhi, 2000, p. 242).

Graph 2. Chinese beer production, 1949-1979 (million liters)

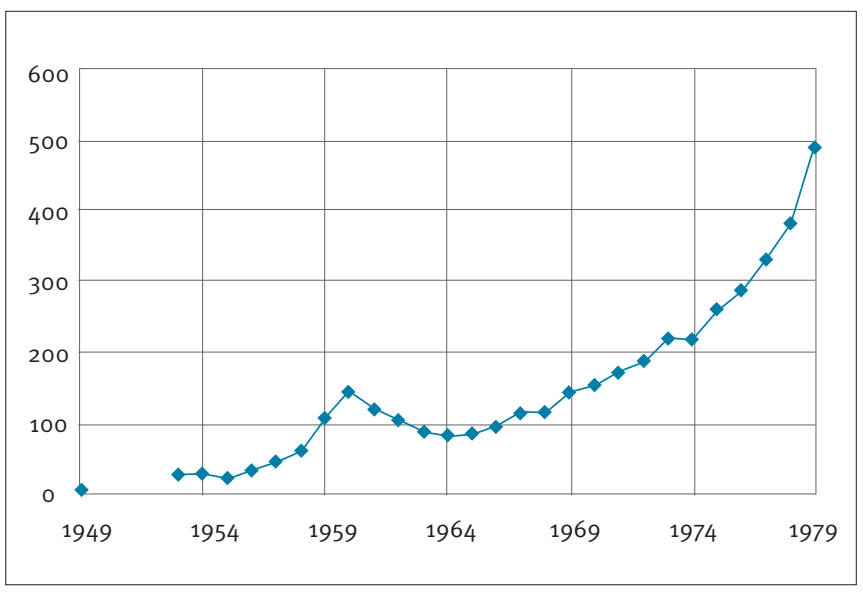

Sources: Zhu \& Qi (1981); Guo (2006, p. 185, 188).

After the launch of economic reforms, production rose from 600 million liters in 1980 to 6 billion in 1990, but industrial structures inherited from the Maoist period persisted into the 1990s and beyond (Guo, 2006). "Literally hundreds of small breweries emerged from the rice paddies," wrote the economist Bai Junfei and his colleagues, with only a measure of hyperbole (Bai, Huang, Rozelle, \& Boswell, 2011, p. 268). The decollectivization of agriculture and the growth of farm productivity made it possible to divert grain to brewing, but factories were still mostly inefficient, state-owned enterprises. “A county's beer factory frequently was its status symbol” (Bai, Huang, Rozelle, \& Boswell, 2011, p. 268). Brewing remained concentrated in industrial centers, particularly along the coast, as it does to this day (see Figure 4). Zhejiang alone accounted for more than 100 of the 741 breweries at the peak of the industry's numerical growth in the mid-1990s. Most of these enterprises were unprofitably small in scale, but local 
officials were reluctant to close them down, as this would cause job losses and damage local pride. Infrastructure continued to limit the distribution of beer to local markets, and consolidation came largely through unsupervised contract brewing, which essentially meant putting the labels of famous beers like Tsingtao and Five Star on inferior local products. With such arrangements, Tsingtao achieved a national presence, but until 1995, the company had a sales force of just two employees, both essentially bookkeepers (Guo, 2006).

Figure 4. Beer Production in China by Province, 2003

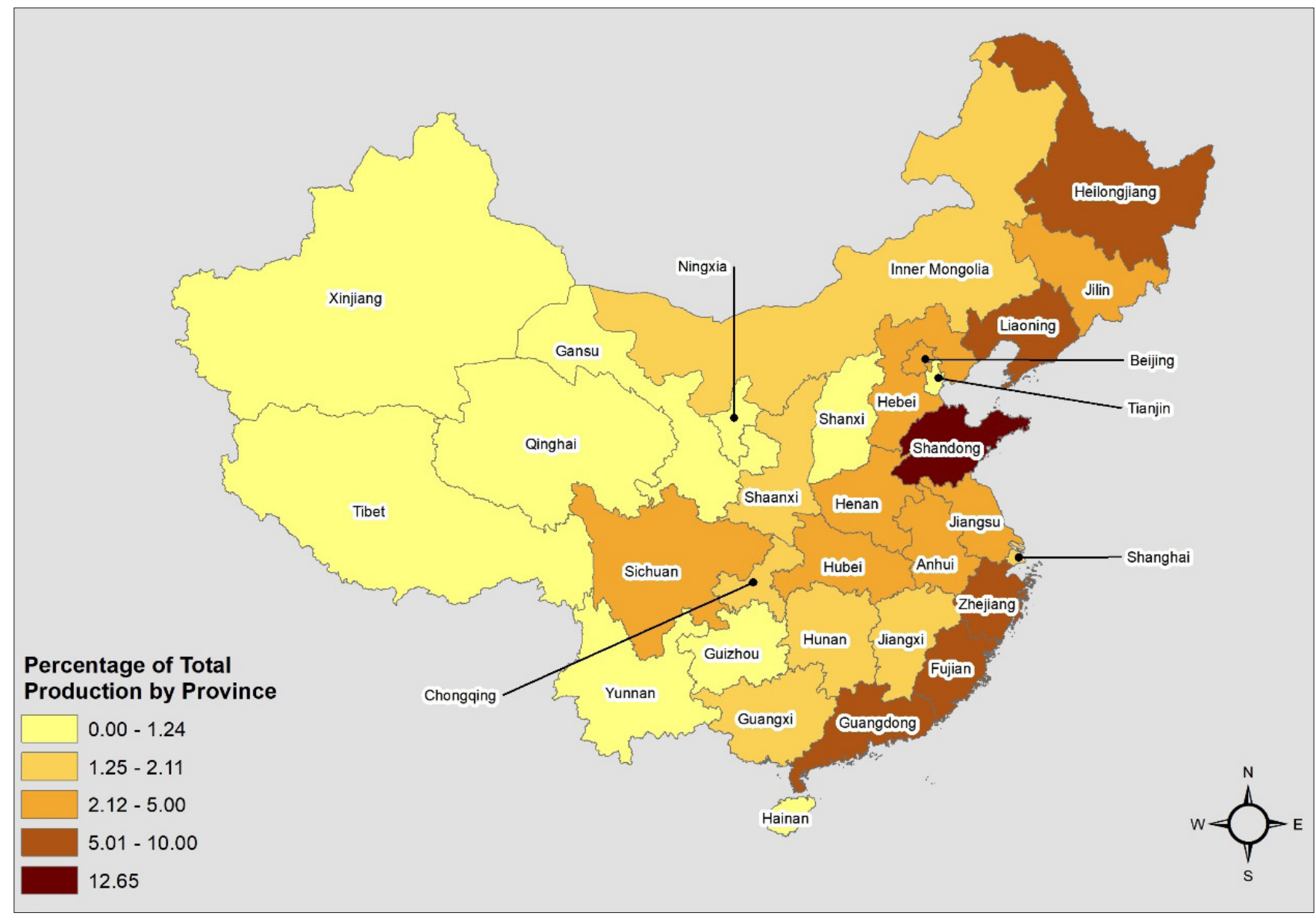

Source: Guo 2006, p. 187. Drawn by William Sturm.

Even as Maoist-era shortages were overcome, beer remained the privilege of urban Chinese society. A map of per capita beer consumption correlates strongly with income: Beijing was at the top, followed by industrial centers along the coast, and the impoverished south and west were at the bottom (see Figure 5). But the map also reveals the historical legacy of beer drinking in the Northeast, particularly in the largely rural province of Heilongjiang. Although quite comfortable financially, in comparison to other agrarian provinces, Northeasterners drink more beer than their counterparts in the far wealthier industrial province of Guangdong, where the tropical heat might seem to call out for cold beer. Per capita averages can conceal wide inequalities within provinces, but a survey of urban consumers at the turn of the millennium found that even among the working poor half of all households consumed beer. Income clearly still mattered, since the highest rates of consumption ( $72 \%$ ) was by the richest $5 \%$ of the population (Cui \& Liu, 2001). Drinking cultures reflected these disparities; while modest urban dwellers might share a beer at domestic family celebrations, the newly rich drank beer regularly in restaurants and nightclubs, such as the brightly lit Taipei-style pijiuwu (beer halls) that became fashionable in Shanghai and Beijing in the 1990 s (Farrer \& Field, 2015; Gold, 1993). 


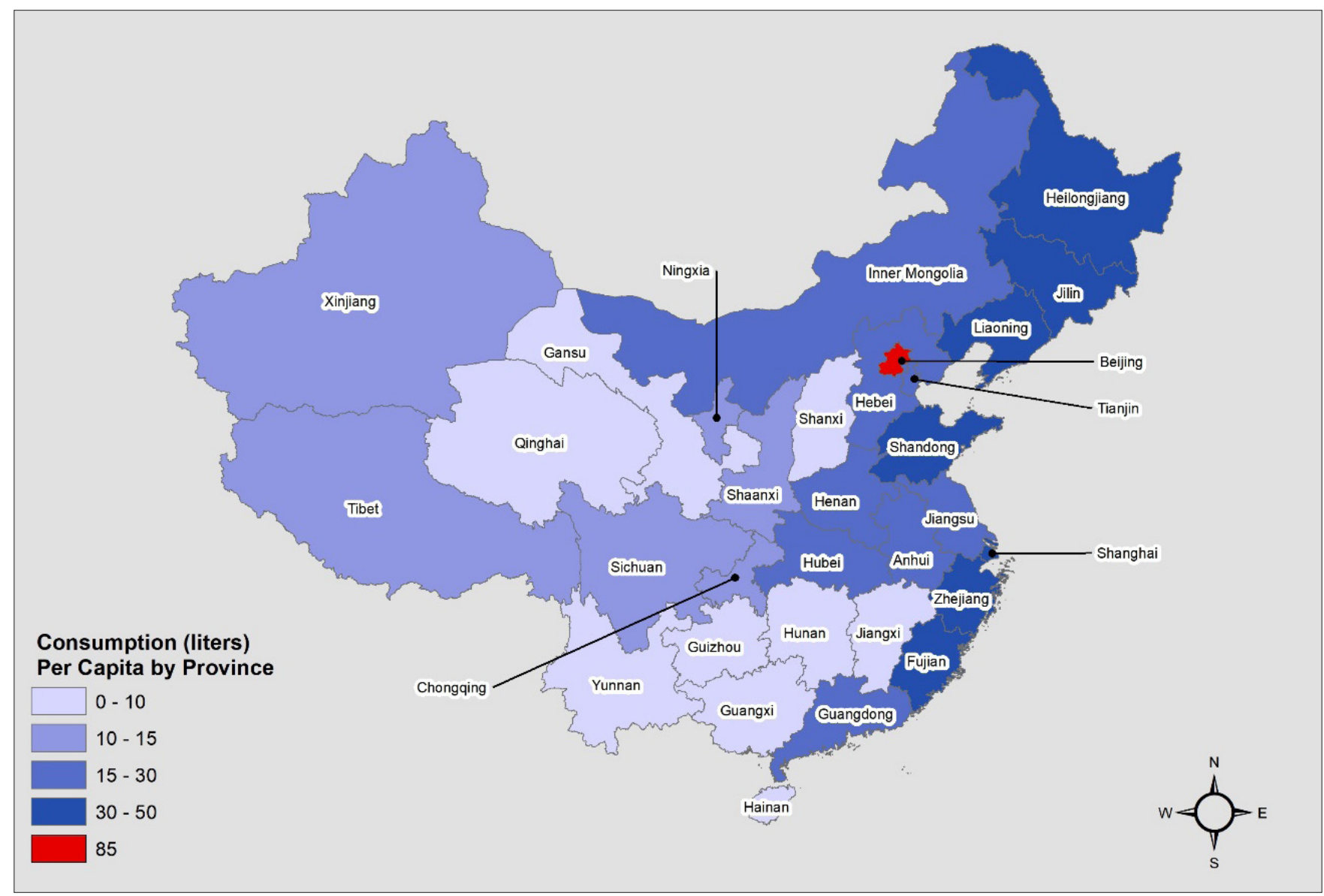

Source: Guo 2006, p. 187. Drawn by William Sturm.

A final legacy of Maoist era brewing was the persistence of low quality, even in the face of global competition. As late as the 1990s, more than half of all breweries reportedly failed quality tests. Shopkeepers and customers alike faced a game of Russian roulette, as by some estimates, roughly one inferior glass bottle in every case exploded before it could be consumed. Wary drinkers learned to fill plastic bags with beer from the kegs displayed prominently in corner stores across urban China (Slocum, 2006; “Beer Too Strong," 1999). But low quality had been a tradeoff that China's original brewmaster, Zhu Mei, was willing to make in order to put beer in the hands of the proletariat. Although capable of brewing full-bodied Munich dark beers, he focused on the cheapest of adjunct lagers, and rather than spend valuable foreign currency on imported pure yeast, he bred his own yeast, overlooking any imperfections that resulted (Zhu 1939b). His plan to build small-scale breweries foundered on the grain shortages of the Great Leap Forward, but he was nevertheless promoted to the rank of senior engineer in the Ministry of Light Industry, where he continued to develop the national industry. By the late 1970 s, beer accounted nearly a fourth of all the alcohol produced in China, a figure that has now grown to nearly 90\% (Guo, 2006). Despite Chairman Mao's preference for the potent liquor Maotai, Zhu had the final word with his plan to convert the Chinese from baijiu to beer.

\section{CONCLUSION}

The available evidence suggests that brewing was a rather ordinary industry in Mao's China, which is to say autarkic, backward, inefficient, politically fraught, and intensely nationalistic. With its modern, industrial production, beer appealed to the CCP as a mildly alcoholic and more grain-efficient alternative to the hard liquor produced in rustic distilleries throughout the Chinese 
countryside. But to achieve that promise required significant work, for the handful of factories that existed in China in 1949 had been neglected during two decades of warfare. Zhu Mei and his colleagues rebuilt the national industry with minimal outside assistance, improvising solutions to the myriad technical complications that arose. The failures of agricultural collectivization severely limited the volume of grain that could be brewed into beer, and the best quality product was, in any event, exported to earn foreign currency. Nevertheless, the communally owned enterprises founded during the Maoist period provided a base for the explosive growth of brewing that followed economic reforms in 1978 .

The experience of Maoist China also has relevance for the marketing of beer around the world, demonstrating that it was not mass advertising alone that made lager a ubiquitous global commodity. Although promotional campaigns and modernist intellectuals in pre-revolutionary China collaborated to develop a genealogy of beer that made it seem simultaneously patriotically local and alluringly foreign, the taste for beer remained limited to a handful of cities before 1949. The CCP seems to have encouraged a much wider demand for beer through non-market forms of conspicuous consumption. Simply put, beer became a form of urban privilege in a society defined by scarcity. Zhu himself provided oblique evidence for this point when he recalled: "During the great famine, no employees of the beer factory experienced dropsy” (Zhu \& Qi, 1981, p. 54). While intended as a testimony to the health qualities of beer, it provided a more telling statement on the profound inequality of food distribution within Maoist China. The great thirst for beer in the decades that followed was in some ways a response to that era of deprivation.

\section{REFERENCES}

1964 quanguo xuexi Qingdao pijiu caozuofa. (n. d.). Money163. Retrieved from http://money.163.com/09/0815/14/5GP1R9NP00253JOU.html.

Alexander, J. W. (2013). Brewed in Japan: The Evolution of the Japanese Beer Industry. Vancouver, BC: University of British Columbia Press.

Ash, R. (2006). Squeezing the peasants: Grain extraction, food consumption, and rural living standards in Mao's China. The China Quarterly, (188), 959-998.

Bai, J, Huang, J., Rozelle, S., \& Matt Boswell. (2011). Beer battles in China: The struggle over the world's largest beer market. In. J. Swinnen (Ed.), The economics of beer, (pp. 267-287). Oxford, UK: Oxford University Press.

Beer and boycott. (1920). The Far-Eastern Review (April), 222.

Beer making in China. (1910). American Brewer's Review 24, 411.
Beer too strong for bottles. (1999). The Advertiser. (March 31), 41.

Beiping Shuanghesheng pijiuchang." [Beijing Shuanghesheng beer factory] (1932). Zhonghang yuekan, 5(2), 128-129.

Berichte, de K. u. K. (1908). Österr. Ung. Consularämter über das Jahr 1907. (1908). Wein: Verlag des Österreiches Handelsmuseum.

Bierausfuhr aus Japan. (1908). Zeitschrift für das gesammte Brauwesen 31(5), 49.

Bierbrauerei und Bierexport Japans. (1906). Globus 90 (21), 339.

Brown, J. (2012). City versus countryside in Mao's China: Negotiating the divide. Cambridge, UK: Cambridge University Press.

Cao Z. (1982). Zhong guo ming jiu zhi [Famous alcoholic beverages from China]. Beijing, China: Zhong guo lu you chu ban she.

Cochran, S. (1999). Inventing Nanjing Road: Commercial culture in Shanghai, 1900-1945. Ithaca, NY: Cornell University Press.

Cui, G., \& Liu, Q. (2001). Emerging market segments in a transitional economy: A study of urban consumers in China. Journal of International Marketing, 9(1), 84-106.

Davis, D. S. (Ed.) (2000). The consumer revolution in urban China. Berkeley, CA: University of California Press.

Dikötter, F. (2006). Things modern: Material culture and everyday life in China. London, UK: Columbia University Press.

Dikötter, F. (2010). Mao's great famine: The history of China's most devastating famine. New York, NY: Walker \& Co.

Domestically produced beer and its market in Sumatra. (1935). Ministry of Foreign Affairs Bulletin, 8(5), 319.

Eyferth, J. (2009). Eating rice from bamboo roots: The Social history of a community of handicraft papermakers in rural Sichuan, 1920-2000. Cambridge, UK: Harvard University Asia Center.

Farrer, J., \& Field, A. D. (2015). Shanghai nightscapes: A nocturnal biography of a global city. Chicago, US: University of Chicago Press.

Foreign Trade Opportunities. (1917). The Brewers' Journal 41(3), 136-137.

Fred Hauswirth, Brewmaster. (1918). American Brewer's Review 32, 230.

Gerth, K. (2003). China made: Consumer culture and the creation of the nation. Cambridge, UK: Harvard University Press.

Gerth, K. (2010). As China goes, so goes the world: How Chinese consumers are transforming everything. New York, NY: Hill and Wang.

Godley, M. R. (1986). Bacchus in the East: The Chinese grape wine industry, 1892-1938. Business History Review, 60(3), 383-409. doi: $10.2307 / 3115883$

Gold, T. B. (1993). Go with your feelings: Hong Kong and Taiwan popular culture in Greater China. The China Quarterly, (136), 907-925.

Guo, Y. (2006). Global big business and the Chinese brewing industry. London, UK: Routledge.

Hoffmann, C. (1971). The Maoist economic model, Journal of Economic Issues, 5(3), 12-27. doi:10.1080/00213624.1971.11502983

Höllmann, T. O. (2014). The land of five flavors: A cultural history of Chinese cuisine. New York, NY: Columbia University Press.

Hong G. (2001). Zhongguo niangjiu keji fazhan shi [History of Chinese Brewing Technology Development]. Beijing, China: Chinese Light Industry Press. 
Jun J., (Ed.) (2000). Feeding China's little emperors: Food, children, and social change. Stanford, CA: Stanford University Press.

Kraus, C. (2015). A microbrewery revolution in socialist China. Retrieved from https://crkraus.com/2015/10/02/a-microbrewery-revolutionin-socialist-china/

Latham, K., Thompson, S., \& Jakob Klein, J., (Eds.) (2006). Consuming China: Approaches to cultural change in contemporary China. London, UK: Routledge.

Li, Z. (2010). In search of paradise: Middle-class living in a Chinese metropolis. Ithaca, NY: Cornell University Press.

Lu, H. (1999). Beyond the neon lights: Everyday Shanghai in the early twentieth ventury. Berkeley, CA: University of California Press.

Luo, X. (n.d.). Chinese Hop Growing. Retrieved from http://www.czhops. $\mathrm{cz} / \mathrm{tc} / \mathrm{pdf} / \mathrm{chinesehop.pdf}$.

Ohlmer, E. (1914). Tsingtau, sein Handel und sein Zoll-System. Tsingtau, China: W. Schmidt.

Parsons, W. B. (1900). An American engineer in China. New York, NY: McClure, Phillips \& Co.

Pijiu gongchang zhi nugong [Female workers in a beer factory]. (1941) Funu Zazhi [The Ladies' Journal], 2(11), 36.

Pilcher, J. M. (2016). Culinary Infrastructure: How facilities and technologies create value and meaning around food. Global Food History 2(2), 105-131. doi:10.1080/20549547.2016.1214896

Qingdao pijiu bainian xuanyan [One Hundred Year Statement of Qingdao Beer]. (n.d.) China.com.cn. Retrieved from http://www.china.com. $\mathrm{cn} /$ market/394643.htm.

Qingdao shizhi shangye juan [Qingdao Municipal Gazetteers: Commerce volume]. (2000). Beijing, China: Wu zhou chuan bo chu ban she.

Reports of the Guangdong Provincial Education Department. (1937). 1(10), 12.

Sanyue shisan ri canguan shuanghesheng pijiu gongsi ji [Visiting Shuanghesheng Beer Company on March 13]. (1920). Quanye congbao [Commercial Repository], 1(1), 46-49.

Shai, A. (1989). Imperialism imprisoned: The closure of British firms in the people's Republic of China. English Historical Review, 104(410), 88-109.

Shen Y. \& Wang Z. (1998). China. In M. Grant M. (Ed.), Alcohol and emerging markets: Patterns, problems, and responses (pp. 123-143). Philadelphia, PA: Brunner Mazel.

Slocum, J. W., Conder, W., Corradini, E., Foster, R., Frazer, R., Lei, D.... Scott, S. (2006). Fermentation in the China beer industry. Organizational Dynamics, 35(1), 32-48. doi:10.1016/j.orgdyn.2005.12.002

Smart, J. (2005). Cognac, beer, red wine or soft drinks? Hong Kong identity and wedding banquets. In T. Wilson (Ed.), Drinking cultures: Alcohol and identity, (pp. 107-28). Oxford, UK: Berg.

Smith, N. (2012). Intoxicating Manchuria: Alcohol, opium, and culture in China's northeast. Vancouver, BC: University of British Columbia Press.

Solinger, D. J. (1984). Chinese business under socialism: The politics of domestic commerce, 1949-1980. Berkeley, CA: University of California Press.

Swislocki, M. (2009). Culinary nostalgia: Regional food culture and the urban experience in Shanghai. Stanford, CA: Stanford University Press.
Thaxton, R. A., Jr. (2008). Catastrophe and contention in rural China: Mao's great leap forward, famine, and the origins of righteous resistance in Da Fo village. Cambridge, UK: Cambridge University Press.

The Brewing Industry in Japan. (1932). Journal of the Institute of Brewing 38, 384

Tsingtao National Brewery. (1958). Shiyong baomi tidao dami zhi pijiu [Replacing rice with corn in beer making]. In Xin yuanliao niangjiu [New Material Brewing]. Qinggongyebu shipin erju. Beijing, China: Qinggongye chubanshe.

United States. Dept. of State, \& United States. Bureau of Foreign Commerce (1908). Commercial relations of the United States with foreign countries during the years 1882-1883 (vol. 1). Washington, DC: Washington, Government Printing Office.

Wilson, T. M. (Ed). (2005). Drinking cultures: Alcohol and identity. Oxford, UK: Berg.

Woodhead, H. G. W. (Ed.). (1926). The China Year Book 1926-7. Tientsin, China: Tientsin Press.

Xiao, Z. (1937). Pijiu zai beiping [Beer in Beijing]. Shibao banquekan [Shibao Biweekly], 2(16), 74-75.

Xu, K. (1917). Qing bai lei chao [Collection of Anecdotes and Romances of the Qing Period]. Shanghai, China: Shanghai Shang wu yin shu guan.

Xu, W. (1939). Fakanci [Opening Remarks]. Niangzao zazhi [Journal of the Chinese Society of Fermentation],1(1).

Yang, Z. (2007). "This beer tastes really good": Nationalism, consumer culture and development of the beer industry in Qingdao, 1903-1993. Chinese Historical Review, 14(1), 29-58. doi:10.1179/tcr.2007.14.1.29

Yasheng H. (2003). Selling China: Foreign direct investment during the reform era. New York, NY: Cambridge University Press.

Yeh, C. V. (2006). Shanghai love: Courtesans, intellectuals, and entertainment culture, 1850-1910. Seattle, US: University of Washington Press.

Yin, X. (1944). “Twenty bottles of beer, let's empty them!” Zhonghua dianying lianhe gufen youxian gongsi yizhounian jinian tekan [Twenty bottles of beer, let's empty them!] Special issue for the oneyear anniversary of China Film Company, Shanghai] (May 1), 1.

Zhang, B. (2008). [Zhang Tingge and Shuanghesheng], Beijing dang'an [Beijing Archives], 5, 47.

Zhang, Z. (2014). Ershi shiji chu habu minzu gongshangye de kaituozhe zhiyi ji shuanghesheng chuangshiren zhang tinge [One of the Economic Explorers in Early Twentieth Century Harbin - On the founder of Shuanghesheng, Zhangtingge]. Heilongjiang Shizhi[Heilongjiang History and Gazetteer], 5, 49-50.

Zheng, Y. (1928). He pijiu ji. [Drinking Beer], Lianyi zhiyou [Friends of Lianyi] 68, 1.

Zhijiu yicong [Collection of Translations of Articles on Brewing]. (19571959). Beijing, China: Bureau of Brewing Industry Management.

Zhu, M., \& Qi Z. (1981). Pijiu jiangzuo yi [Lectures on Beer]. In Heilongjiang fajiao [Heilongjiang Fermentation]. Harbin, China: Helongjiang sheng qingongye yanjiusuo. 
Zhu, M, Qi Z., \& Wu G. (1980). Zhongguo niangzao gongye sanshinian de jishu chengjiu [Thirty years achievements of Chinese Brewing Industry]. Helongjiang niangzao [Helongjiang Brewing], 2(1980), 39-43.

Zhu, M. (1939a). Pijiu de lishi. [The History of Beer]. Niangzao zazhi, 2, 17-18.

Zhu M. (1939b). Pijiu jiqi fajiaojun geiyu ren zhi yingxiang. [The Impact of Beer and its Yeast on Humans]. Niangzao zazhi, 1, 8-11.
Zhu, M. (1958). Zenyang ban xiaoxing pijiu chang [How to Run a SmallScale Brewery]. Beijing, China: Light Industry Press.

Zhu, M. (1990). Mantan zhongguo pijiu sishi nian. [Forty Years of the Chinese Beer Industry]. Niang Jiu [Liquor Making], 10, 30-33.

Zhu, M. (1991). Nanwang de suiyue [Unforgettable Years]. Niang Jiu [Liquor Making], 2, 49-51. 